Canadian University Music Review

Revue de musique des universités canadiennes

\title{
R. Murray Schafer. R. Murray Schafer On Canadian Music. Bancroft: Arcana Editions, 1984, x, 105 pp.
}

\section{Robin Elliott}

Numéro 5, 1984

URI : https://id.erudit.org/iderudit/1014015ar

DOI : https://doi.org/10.7202/1014015ar

Aller au sommaire du numéro

\section{Éditeur(s)}

Canadian University Music Society / Société de musique des universités canadiennes

\section{ISSN}

0710-0353 (imprimé)

2291-2436 (numérique)

Découvrir la revue

\section{Citer ce compte rendu}

Elliott, R. (1984). Compte rendu de [R. Murray Schafer. R. Murray Schafer On Canadian Music. Bancroft: Arcana Editions, 1984, x, 105 pp.] Canadian

University Music Review / Revue de musique des universités canadiennes, (5), 330-332. https://doi.org/10.7202/1014015ar

All Rights Reserved (C Canadian University Music Society / Société de musique des universités canadiennes, 1984
Ce document est protégé par la loi sur le droit d'auteur. L’utilisation des services d'Érudit (y compris la reproduction) est assujettie à sa politique d'utilisation que vous pouvez consulter en ligne.

https://apropos.erudit.org/fr/usagers/politique-dutilisation/ 
rather than throw light on, a passage under scrutiny. An orchestral section from Lutoslawski's Trois Poèmes d'Henri Michaux is categorized as "a constantly poly-metric, periodically single-phase construct using the divisions $1 / 2,3 / 4,5 / 8^{\prime \prime}$ (p. 139). Here the terrifying and grotesque linguistic specters of Die Reihe and Perspectives of New Music may begin to materialize, only to be confirmed in their immanence by a resort to time measurements which are used to demonstrate "the palindromically symmetrical pattern of attack distances..." (ibid.) and "the complexity of the varying time distances between the attacks..." (ibid.). Now this is using a jack-hammer to crack an almond. The simple fact is that Lutoslawski, in order to create a mass-sound, has resorted to an old trick, beloved of Stockhausen, of combining in simultaneity rhythms that have a harmonic and equal phase relationship with each other; we have, in this case, an incomplete harmonic rhythmic spectrum containing partials $2,3,4,5$, and 8 . Understood in this light the palindromic construction of note attacks within the beat results quite naturally from the harmonic division of that beat, and no misleading significance need be implied by that pattern. This still does not, of course, tell us why such a procedure was employed, but at least it does not suggest a complexity of technique that is clearly at odds with the reality. It may also help to avoid an inexplicable error of observation where it is stated, in a following sentence to those cited above, that "the 500-millisecond durations are not [stress Anhalt's] employed to mark the beginning of, and the half-way point between, the beats..." (pp. 139-40). A perusal of the passage in question reveals that these "500millisecond durations" do, indeed, mark off the half-way points (see cl. II, tbn. I, in Ex. 4.10 p. 119). Anhalt's description of this passage as non-periodic (p. 140) is also puzzling.

One other error which ought to be mentioned is the misspelling of Werner Meyer-Eppler (not Mayer-Eppler). This appears both on page 106 and, more importantly, in the index (p. 325).

Alternative Voices is by no means an easy book to read and digest. In its tone of language and in its concern with detail and bibliographic substantiation it is not unrelated to that most indigestible of literary forms: the doctoral thesis. But perseverence certainly brings rich rewards. It is the sort of book that can turn one's mind to contemplate things (not just music) from a totally fresh perspective. Despite some infelicities of style it is to be welcomed as a very significant and muchneeded scholarly work in this area.

David Piper

R. MurRay SCHAFER. R. Murray Schafer On Canadian Music. Bancroft: Arcana Editions, 1984, x, 105 pp.

Here in one slim volume is a baker's dozen of articles on Canadian 
music by R. Murray Schafer. Written over the course of twenty years1963-1983 - all have appeared in print before and most will be familiar to those who have been following the Canadian musical scene in general or Schafer's career in particular. Some of the articles have been revised for inclusion in this anthology: "The Public of the Music Theatre-Louis Riel: A Case Study," for example, first published as a pamphlet by Universal Edition in 1972, has been cut down in size, while "Canadian Culture: Colonial Culture" is somewhat expanded from its first appearance in print in the March 1984 Canadian Forum to include an attack on the National Arts Centre as well as the Canadian Broadcasting Corporation. "Music in the Cold," although it contains the full original text, is much less effective in regular print than in its earlier pamphlet form, which featured cold blue type huddled at the bottom of expanses of snow-white paper. The book is attractively packaged, with original Schafer drawings on the cover and scattered throughout the book, and thirteen black-and-white photographs, some of which seem to have no immediate relevance to the text, and two of which have the captions reversed. It is available in both paperback and hardback editions.

What is most immediately apparent on reading through all the writings again is the shift in Schafer's rhetoric from an internationalist stance in the 1960s to a moderate nationalism in the more recent articles. In this respect Schafer runs counter to the flow of Canadian intellectual currents, which saw a flourishing of left-liberal nationalism crest with the Centennial celebrations only to be dismantled and shelved with the onset of an economic tailspin and rampant neoconservatism in the following decade. One suspects that Schafer enjoys, even cultivates, the role of the outsider, stirring the consciousness of the mainstream by his ever contradictory attitudes. He makes no secret of the shift in his thinking; rather he draws attention to it, both in the Preface, where he states that "the essays ... display many deflections of thinking which I have made no attempt to reconcile" (p. vii) and in "Canadian Culture: Colonial Culture" where he does in fact attempt to explain, if not to reconcile, his change of position (see especially pp. 7778 in this regard).

Under the changing surface, however, there is a common thread, or rather several common threads, running through all of the essays in this book. Some of these threads include such topics as the evils of art as market produce and, related to this, Schafer's mistrust of patronage and business involvement in the arts. At least half the essays are partly or wholly given over to a venting of frustration and anger on this count, from "What is this Article About?" of 1964 to "Canadian Culture: Colonial Culture" of 1983. A closely connected issue is first stated in the Preface and elaborated upon in one way or another in virtually every article, namely Schafer's contention that "Canada is enslaved to cultural models which originated outside its territory" (p. viii). This assumption is behind his labelling opera companies and 
symphony orchestras as "pet dinosaurs" (p. 41) but it also, more positively, surfaces in his own search for an appropriate artistic response to the harsh realities of the Canadian landscape. Schafer often flails against the prevailing centrist view of culture, whether the dominating center is Europe, America, or Toronto. Already in 1967 he had complained of "centrifugal flinging of culture out from the big centres to the small centres, a matter which stimulates more resentment than is generally realized" (p. 42). His own response has been to oppose to this a view of specifically Canadian culture shaped by climate and geography. Taking this idea to its logical conclusion, Schafer ends the book with the introductory notes to the scores of Music for Wilderness Lake and The Princess of the Stars, two recent compositions in which the Canadian environment is part of the work of art (although not an inextricable part, as Music for Wilderness Lake was transported to Amsterdam-no doubt for Schafer a satisfying reversal of the centrifugal force). This line of Schafer's thought is often taken purposely to extremes with sometimes whimsical results-as in "Music in the Cold" -and sometimes provocative results-as in "Canadian Culture: Colonial Culture"-where he fantasizes that "it would be a good idea if all government funding for the arts was removed entirely. Then we would see who the survivors were" (p. 92). Ah yes, survival as the great Canadian symbol. Perhaps if financial restraints continue to be the order of the day, Schafer's fantasy will come true, and we will find out not only "Where is here?" but also "What does here sound like?"

It is perhaps a matter of bad timing that Schafer should have written in the Preface that "the chair in Canadian musicology is still largely vacant despite the admirable work done by a few researchers" (p. vii) when John Beckwith has recently been named to the Jean A. Chalmers Chair of Canadian Music at the University of Toronto. It is no doubt ironic, given Schafer's feelings about patronage, that the first chair in Canadian musicology should be provided by a noted patroness of the arts. Then too, the phenomenal growth in activity in the field of Canadian music studies must surely count as more than "admirable work done by a few researchers." This is mentioned only by way of pointing out that Schafer's views and critiques, incisive and much needed as they are, tend sometimes to be overly polemical, painting complex issues in bold colors and drawing up sides for and against. It is a certain method of stirring up controversy, but often fails to give credit where credit is due. This, however, is only to state the obvious about Schafer, for he clearly sees his role to be that of reshaper and reformer of Canadian music. It is a sad fact of Canadian history that most of our great reformers have also been great failures, appreciated only after their cause was lost. Given such precedents, it is an act of considerable courage for Schafer to cast himself in this role. This book is a provocative manifesto for his cause. 